\title{
The Latin translations of Confucius' Dialogues (Lun Yu). A comparison of key concepts
}

\section{Introduction}

The teaching of Confucius ${ }^{1}$ is contained in the so-called Chinese Classics and then expanded through innumerable commentaries. The Chinese Classics are divided as The Five Canonical Works, or Five Qing (五经): Book of Songs (诗经); Book of History (书经); Book of Changes (易经); Book of Rites (礼经); Spring and Autumn Annals (春秋); and the Four Books (四书): Analects (= Dialogues, 论语); The Book of Mencius (孟子); The Great Learning (大学); The Doctrine of the Mean (中庸之道). The Four Books are traditionally attributed to four different philosophers: the Analects (= Conversations, Dialogues, 论语) are sayings of Confucius; the Book of Mencius (孟子) is attributed to Mencius; the Great Learning (大学) to Ceng Can (曾参), a disciple of Confucius; The Doctrine of the Mean (中庸之道) to Kong Ji (孔伋), the grandson of Confucius.

As far as the Dialogues (论语) are concerned, there exist six main complete Latin translations. The first translation was done by the Jesuits Michele Ruggieri (罗明坚) and Matteo Ricci (利玛窦) around the year 1592. ${ }^{3}$ The second is Confucius, Sinarum Philosophus, sive Scientia Sinensis Latina exposito studio et opera Prosperi Intorcetta, Christiani Herdtrich, Francisci Rougemont, Philippi Couplet,

1 One clear and brief presentation of Confucianism is in Yao (2000). See also Fung (1952) 48-49; Filippani (1964) 39 and Ferrero (2004).

2 Cf. Legge (2006-1861-1872) 1: “The term Qing is of textile origin, and signifies the warp threads of a web, and their adjustment. An easy application of it is to denote what is regular and insures regularity. As used with reference to books, it indicates their authority on the subjects of which they treat”.

3 See FR I, 43 n. 2. In the National Library 'Vittorio Emanuele II' in Rome there is a manuscript (Fondo Gesuitico n.1185/3314 ) with the head-title A P. Michaele Rogerio collecta (material collected by Father Michele Ruggieri). Professor D'Arelli has already studied the historical background of this manuscript: see D'Arelli (1994), (1996) and (1998). His articles describe the manuscript and its origin, analyse the writer's ductus and the material used, provide precise original page numbers, and discuss early findings and scholars' opinions. An edition in Italian language has been published by LAS, Rome, in July 2019. The critical edition with transcription and translation will be published by Beijing Foreign Studies University soon: see also Ferrero (2016).

Ә OpenAccess. () 2019 Michele Ferrero, published by De Gruyter. (cc) BY-NC-ND This work is licensed under the Creative Commons Attribution-NonCommercial-NoDerivatives 4.0 License. https://doi.org/10.1515/9783110616804-006 
PP. Soc. Jesu, Paris $1687 .{ }^{4}$ Intorcetta, Herdtrich, Rougemont, and Couplet were all Jesuit missionaries. Couplet's Confucius Sinarum Philosophus has a much longer and complex translation compared with others. The four translators also add explanations and comments to the original text. Couplet says, in the title that his work is versio literalis una cum explanatione (translation and explanation together). It was indeed the style of that age. We could call Couplet's rich and abundant translation almost 'baroque'. We can see clearly the complexity of Couplet's translation compared with Zottoli's short and concise style. For example, the sentence 則勿憚改”, for Legge is “When you have faults, do not fear to abandon them”, for Zottoli et si erras, tunc ne formides emendari (if you make mistake, do not be afraid of correcting), while for Couplet is "remember the human condition, that is frail and leaning towards faults and easily commit sins, and if you fall into sin do not fear or hesitate to correct what is wrong and stand up with effort and free yourself from the chains and difficulties that you feel are an obstacle keeping you down”. Baroque, indeed!

Another translation is contained in Francisci Noel Sinensis imperii libri classici sex : nimirum Adultorum Schola, Immutabile Medium, Liber Sententiarum, Memcius, Filialis Observantia, Parvulorum Schola, Prague 1711. Francois Noel (卫方济) (1651-1729), too, was a Jesuit missionary.

Then there is Les quatre livres, by Seraphin Couvreur, also a Jesuit (顾赛芬), 1895, in Latin and French.

At the end of the $19^{\text {th }}$ century a new translation was published: Cursus litteraturae Sinicae neo-missionariis accommodatus (1879-1892), by another Jesuit, Angelo Zottoli (晁德莅) (1826-1902).

Finally, there is William Cheung's multilingual Confucius online project. It is a text available only online: http://www.confucius.org/. The Latin translation is based on the English one.

The Jesuit missionaries to China introduced Confucius into the Western world using Latin. This was the first meeting between the teaching of Confucius and Europe. It occurred in the language of Cicero and the Vulgate Bible. This is historically significant. Latin is the language of ancient Western wisdom. The first meeting between Chinese wisdom and European history was mediated by Latin, the language of wisdom par excellence.

Confucius' sentences are a treasure for all mankind. In their Latin translation they became also a bridge between cultures, ages, traditions. The first trans-

4 See Meynard (2011) and Luo (2012). 
lators of Confucius into Latin had studied Latin with Cicero as a model. ${ }^{5}$ By using words that belong to a different history and tradition, did they also offer new interpretations to the Confucian texts? Those Confucian texts have been interpreted and commented upon for centuries. Did those Latin translations and 'Western' interpretations offer any new approaches to Confucius? Did the first Western translations expand on the original wisdom of the Chinese master?

Without doubt, those first translations had a particular flavor. Most of those translators were Christian missionaries. They wanted to present Confucius as compatible with the Christian faith. ${ }^{6}$ Did they alter the original meaning in order to achieve their objective? Or were they trying to do with Confucius what Thomas Aquinas had done before, using Aristotle as the background for his theology? As it is written in Ricci's Storia dell'introduzione del Cristianesimo in Cina (History of the Introduction of Christianity in China), "Il Padre procurò di tirare alla nostra opinione il principale della setta de' letterati, che è il Confutio, interpretando in nostro favore alcune cose che aveva lasciato dubiose". ("The Father [Ricci] strove to show that Confucius is near our side, by interpreting to our advantage some things he left uncertain").

By comparing various Latin translations of passages of Confucian Classics, I would like to show first of all that those translators were faithful to the original. They liked Confucius because of what he taught and wanted to introduce him to the West. It was unavoidable that they sometimes read him according to their own personal and historical background. Moreover, in some cases, they enriched the original text by using particular Latin words that have a different historical background. If we look at their conduct as a whole, they had the same respect for Confucius that in the past translators showed towards Plato and Aristotle, or Virgil.

Various languages inevitably add different nuances to a text. A translation indeed always misses and loses something of the original but can also augment and expand meaning. According to Michail Bachtin, the meaning found in any dialogue is unique to the sender and recipient and based upon their personal

5 The grammar school of the Jesuits was organized along five sections, or 'classes', whose objective was to help students to achieve, through a constant practice of memory and exercise, a "perfect eloquence". The first three classes were for grammar, the fourth for humanity, the fifth as preparation for further studies of rhetoric. As mentioned above, the time of each "class" depended on the speed of the student. In Macerata Ricci studied grammar and humanity, but not rhetoric. During the grammar class the students were taught Italian and Latin, their model being Cicero. See Fois (1984) and also Villoslada (1954).

6 On attempts to make Confucius almost a Christian, see Rule (1986).

7 FR, n. 709. 
understanding of the world as influenced by their socio-cultural backgrounds. "Bachtin's dialogism opens up space for communication scholars to conceive of difference in new ways" and this "dialogic perspective argues that difference (of all kinds) is basic to the human experience". ${ }^{8}$ A different language is not only an obstacle in communication, but also a source of new meaning. Culture and communication are closely related. The understanding, according to Bachtin, of a given utterance, text, or message, is contingent upon one's cultural background and experience. This means that a reader can see in the text even more than the authors put into it, making not only writing but also reading a creative process. As Wolfgang Kubin says: "translation is a matter of choice and decision, of selection and possibility, of history and knowledge". ${ }^{9}$

For this reason, the meeting between this Chinese Confucian text and Latin is particularly enriching for the text itself. We can consider Latin as one of the main representatives of Western culture. The cultural heritage of the West, with its roots in Greek, Roman, and Judeo-Christian traditions, has been transmitted in Latin for 2000 years. Latin words have a unique echo in the ears of the readers. Thus, a Latin translation of the basic text of Chinese culture is an extraordinary meeting between two civilizations. The Dialogues, as any other classic, grows in time, through different interpretations and different translations.

In this article, I offer some examples of this dialogue between Western and Eastern cultures as they occurred through these translations. I select certain lines of Confucius as they appear in Chinese, English, and Latin. The comparison between these three languages, which had and still have a widespread influence on the entire world, shows the depth of Confucius and his universal appeal.

\section{1 'Wisdom' and 'study' (学 - xue)}

'To study' (xue 学) in the Confucian tradition is the way to redemption and human fulfillment. For Christianity, salvation comes from God's grace. For Confucius, it comes from education and study. To study gives meaning to life. The basic standard for the Confucian educational and moral program is contained in the book called 大学 ( $D a$ Xue, The Great Learning). Xue (学) is different and deeper than learning data or memorizing information. It indicates the process of becoming more human, similar to the Greek idea of paideia. For Confucius,

8 Baxter (2006) 102.

9 Kubin (2012) 334. 
"to study" includes principally learning that the most important element of reality is proper human relationship within a hierarchically-ordained society.

Confucius considers education the main tool in the process of the cultivation of virtue (修道) and the achievement of full humanity. Education does not merely aim at conveying knowledge, but also at shaping correct behavior patterns and internalizing them as part of one's character. Xue (学) is the way to become a gentleman (君子), a good man, a person who has achieved a fulfilled life in moral perfection and social propriety.

The target of education is not 'knowledge' but 'a good life', or the art of knowing how to live life well. For historical reasons, in the Western world 'education' and 'ethics' are today considered two different disciplines. No teacher today would see himself or herself as a 'sage'. They teach a 'subject', not 'how to live'. Yet in the Confucian tradition ethics and education coincide.

Given the importance of this concept in the Confucian tradition, we can appreciate the beauty, richness, and depth of its Latin translation. At the same time, we see the challenges of a suitable translation. The Latin words employed in the translations attempt to explain that Xue (学) is something distinct from 'studying'.

For example, Zottoli translates Xue (学) ‘to learn wisdom', studere sapientiae. Studere sapientiae echoes in Latin the Book of Proverbs of the Bible: disce sapientiam! (Prov. 6.6). In Couplet's Latin translation of 1687, it is translated: operam dare imitationi sapientum ('to imitate the wise men'). So, the words Xue (学) and $X i$ (习) are interpreted not just as any learning, but as a specific study of 'wisdom', in Latin sapientia.

Let us see an example by comparing the six Latin translations of the first sentence of the Dialogues, giving the reading of the manuscripts and correcting only the evident mistakes. I also add the English translation by James Legge ${ }^{10}$.

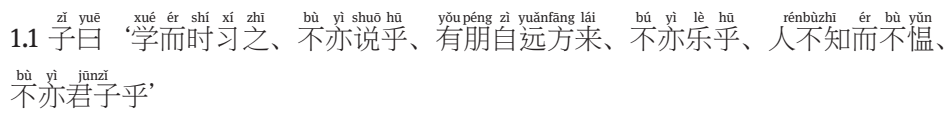

Legge: 1 . The Master said, "Is it not pleasant to learn with a constant perseverance and application?

2. "Is it not delightful to have friends coming from distant quarters?

3. "Is he not a man of complete virtue, who feels no discomposure though men may take no note of him?”

Ruggieri: Addiscenti virtutis iter recte agendi rationem tradit. Qui numquam per incuriam abiens qua didicit, meditationem ac pertractationem desistit, ubi ad perfectionis culmen per-

10 Legge (2013-1893). 
maneret quanta tandem laetitia perfundetur! Societate aliqua coniuncti, si ad discendum videlicet virtutis iter e longinquis remotisque locis in unum confluant nonne gaudendum sibi vehementer existimabunt? Si quis virtutis itinere iam confecto, nullam se apud alios virtutis suae opinionem excitasse moderate ferat, quod est quod ad summam probitatem perfectionemque desideret.

Couplet: Operam dare imitationi sapientum et assidue exercitare sese in huiusmodi studio imitandi, nonne olim delectabile erit? [...here Couplet adds a comment]. Postquam autem te excolueris tam feliciter huiusmodi cum labore et constantia, si dentur tunc sectatores et amici e longinqua regione adventantes, consulturi te atque in disciplinam tuam tradituri sese, fama scilicet virtutis ac sapientiae tuae excitati, nonne tum multo etiam vehementius laetaberis et prodes omnino sensum hunc exultantis animi tui? Verum si plane contrarium acciderit at cum talis ac tantus sis, ab hominibus tamen si ignoreris, nemo te consulat, suspiciat nemo; tu interim hanc ob causam non affligaris nec indigneris; quippe contentus iis quae tibi ipse peperisti et possides securus; nihil autem de his quae extra te, alienique sunt arbitrii, laborans; nonne perfecti viri consummataeque virtutis hoc erit?

Noel: Confucii effatum: qui priscorum sapientum facta non tantum imitatur, sed etiam cum illis assidue se ad ulteriorem profectum exercet, numquid is gaudio impletur? Deinde, cum a remotis plagis adveniunt socii, ut eius praecepta excipiant; numquid etiam gaudio diffluit? Si tamen ab hominibus nesciatur, nec ob hoc irascatur; numquid tunc potest vere dici vir sapiens et consummatus.

Couvreur: Magister Confucius ait: qui colit et omni tempore recolit illud (qui sapientium praecepta discit et exsequitur, indesinenter recolens discit et exsequitur) nonne quidem gaudet? Si sint pares (ut eum audiant), nonne quidem laetatur? Si homines non noverint eum, et non aegre ferat, nonne quidem est vir sapiens?

Zottoli: Confucius ait: studere sapientiae et jugiter exercere hoc, nonne quidem jucundum? Et si erunt sodales ex longinquo loco venientes, nonne quidem laetaberis? Si non, ab aliis nesciri et non indignari, nonne etiam sapientis est?

Cheung: Confucius dixit: nonne discere et identidem tractare quae didicisti voluptas est? Nonne amicos habere qui ex longinquo ut doctrinam communicet veniunt felicitas est? Nonne aequo animo ferre quod ab aliis non recte aestimaris ingenui est?

We notice this variety of Latin words: didicit (disco); meditationem ac pertractationem; imitationi sapientum; exercitare sese; studio; excolueris; cum labore et Constantia; priscorum sapientum facta; exercet; colit et recoli; sapientium praecepta; discit et exsequitur; studere sapientiae; iugiter exercere; discere; tractare quae didicisti

Human flourishing does not come from conformity to God's will or divine commandments or plan, as in the Christian-Western tradition, but from a personal effort to 'study' and 'learn' the traditions of the ancestors. Thus the meaning and purpose of life is found in this 'studying'. Since studying requires teachers and books, in China, from ancient times until today, teachers, books, libraries, 
reading, learning, and similar activities are esteemed and appreciated above everything else.

Let us see another example:

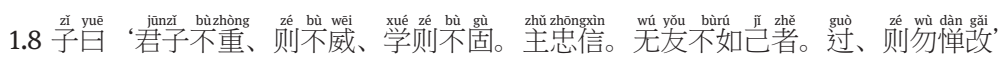

Legge: The Master said, "If the scholar be not grave, he will not call forth any veneration, and his learning will not be solid.

2. "Hold faithfulness and sincerity as first principles.

3. "Have no friends not equal to yourself.

4. "When you have faults, do not fear to abandon them."

Ruggieri: Nulla potest eius esse auctoritas, qui graviter matureque non agit ac proinde inanem quandam sapientiam sequetur. Studeat igitur solidae virtuti, mendaxque ne sit neve ad amicum se deteriorem adiungat. Si quod peccaverit, poenitentia corrigere ne erubescat.

Couplet: Probus vir si idem non sit vir admodum serius, habeat quoque cordi exteriorem gestuum motuumque omnium moderationem et gravitatem [...] scientias ac disciplinas quas tanto studio et labore acquisivit, sane non diu conservabit. [...]

Memor interim conditionis humanae, quae imbecillis [sic] est pronaque in lapsum et peccare facilis, si te peccare contigerit, tum quidem ne timeas dubitesve corrigere quod peccatum est et cum nisu quoque ac labore surgere, perruptis generose vinculis ac difficultatibus, quibus impediri te sentis ac deprimi.

Noel: Confucii effatum: sapientiae alumnus, si morum gravitatem non amarit, mox modestia carebit, qua destitutus, licet sapientiae disciplinis vacet, non tamen diu persistet. Deinde animi candorem et veritatem inprimis colat. Quod ad socios attinet, non frequentet nisi eos, aut qui sibi praecellunt aut qui sibi sunt pares. Denique cum quis sine culpa vivere non possit; sua vitia assidue corrigere, non illum taedeat.

Couvreur: qui colit virtutem, nisi sit gravis (animo et habitu) tunc non obtinet reverentiam, discit tunc non firmiter. Pro re praecipua habeat non similes sibi (non virtutis amantes); si erret, tunc ne refugiat sui corrigendi laborem.

Zottoli: Philosophus ait: probus vir, non gravis, jam carebit auctoritate, et studia jam erunt sine soliditate: caput sit fidelitas et veracitas, nullumque habeas amicum haud similem tibi ipsi, et si erras, tunc ne formides emendari.

Cheung: Confucius dixit: sine constantia vir ingenuus non coleretur, nec foret eius doctrina integra. Dum amicos hortatur ut fideles et fidi sint, nullum habet amicum quin sibi par sit. Non dubitet eius vitia corrigere.

学则不固 (Xue ze bu gu) expresses the solidity and quality of your learning. It is explicitly linked with proper human social relations: your learning must be recognized by others. Therefore your external behavior should almost irradiate your inner knowledge. The Latin words auctoritas, gravitas, reverentia, constantia, so dear to Cicero in his De officiis, convey also the meaning of learning as achieving a higher status in society. 
In the following examples the Latin translations beautifully express this concept: for Confucius 学 (xue, 'to study') is not just about books. It is about a generous life, a good behavior, a proper relationship with others。

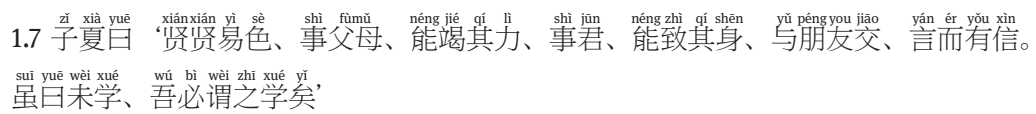

Legge: "Tsze-hsiâ said: If a man withdraws his mind from the love of beauty, and applies it as sincerely to the love of the virtuous; if, in serving his parents, he can exert his utmost strength; if, in serving his prince, he can devote his life; if, in his intercourse with his friends, his words are sincere:- although men say that he has not learned, I will certainly say that he has".

Ruggieri: Qui probitatis, quasi formosissimae cuiusdam mulieris amore captus, omni [sic] animi provisionem cavet, ne quod erga parentis officii praetermittat, qui se totus penitusque fingit ad regis imperium, qui cum altero contrahens, fideliter contrahit; hunc ego disciplinae expertem tametsi nihilusque didicerit, non censeo.

Couplet: Si delectetur quis viris probis ac sapientibus sic ut commutet et quasi transferat in hos amorem quo ferri solet in res visu pulchras ac delectabiles: id est, si cum eo impetu atque ardore amoris appetat adolescens virtutem ac sapientiam, quo aetas ista plerumque rapi solet ad oblectamenta sensuum. Item in praestando probi filii officio tam erga patrem quam matrem, si valeat, seu velit et conetur exhaurire suas vires: ad haec, si debita subditi officia sic praeter adversus suum regnum aut principem, ut valeat, sive non dubitet exponere propriam quoque personam ac vitam quotiescunque res ita postulaverit. Denique cum sodalibus et amicis suis vivens familiariter si tales instituat sermones, ut ubique locum habeat, seu eluceat fides ipsius ac veracitas; quisquis huiusmodi fuerit, tametsi forte sint qui dicant eum necdum studuisse, ego certe semper et sentiam et dicam studuisse et praeclare quidem esse doctum.

Noel: Si quis tanto sapientium virorum sapientiam, quanto rerum pulchrarum pulchritudinem amore prosequatur; si in deferenda parentibus observantia omnes vires intendat, si in praestando regis obsequio mortem ipsam non reformidet; si in tenenda amicorum societate illibatam verborum veritatem servet; quamvis forte mihi dicatur hic vir litteris non vacasse; ego tamen eum verum esse litterarum alumnum assevero.

Couvreur: Tzeu hia ait: qui in observantiam et amorem sapientium commutat amorem voluptatum, qui operam praebens parentibus potest totas adhibere suas vires, qui operam praebens principi potest totum impendere seipsum, qui cum amicis conversans loquitur et habet veracitatem, etsi dicatur non studuisse sapientiae, ego certe dico eum studuisse.

Zottoli: Tse hia ait: prosequendo sapientes mutans voluptatum armorem (贤贤易色), serviendo parentibus sciens exhaurire suas vires, serviendo principi valens devovere suam personam, cum amicis versatus loquens cum sinceritate, licet dicatur nondum studuisse sapientiae, ego certe dicam illum studuisse.

Cheung: Virtutem pulchritudinis loco magnopere observare, omnes vires conferre ut parentibus servias, velle dum domino servis mori, fideliter in negotiis cum amicis susceptis loqui, hoc assero didicisse, etsi alii aiunt hoc esse nihil didicisse. 
For Confucius 'learning' in itself is the higher value. To study is a necessary element of human growth because study is necessarily connected with moral improvement.

Sapientia is the object of study - it is a higher level of knowledge. Somehow in these Latin translations Confucius appears similar to Socrates, who searched for wisdom but never wrote a book. Western history recorded the clash between Socrates and the Sophists about the danger of using learning and rhetoric for making money rather than for personal improvement and the search of truth $^{11}$. However, there is a visible difference between Confucius and Socrates. The first considers the traditions of the ancients the main source of wisdom, the latter considers traditions as the main source of debate.

Confucius himself does not hesitate to boast proudly of his own love of study:

\subsection{8子曰“十室之邑、必有忠信如丘者焉、不如丘之好学也}

Legge: "The Master said: In a hamlet of ten families, there may be found one honorable and sincere as I am, but not so fond of learning”.

For Confucius, a man can be good even without learning from books. However, unlike in the Greco-Roman tradition, a man who studies, learns things, reads books, memorizes notions, and collects information is always also expected to be morally good. Recently in the newspapers there was a story of a female passenger slapping a check-in staff member on the face, because she arrived late to the check-in and was informed that her flight had stopped at 9: $35 \mathrm{am}$ (see http:// www.globaltimes.cn/content/1050696.shtml). Where was the news? The culprit is described as 'a PhD candidate' and as such should be morally above others.

\section{Gentleman (君子 - junzi)}

One of the main objectives of Confucius' teachings is to form a 'gentleman', Junzi (君子), a man who strictly follows the Rites ( $i$, 礼), a man who finds his right place in the society and lives it out through his virtues. By participating in social life in the right way a person becomes a gentleman. ${ }^{12}$ 君子 is for Legge "the superior man”, an expression that perhaps Friedrich Nietzsche would have liked ${ }^{13}$.

11 For example in Plato's Gorgias.

12 See also Peerenboom (1993) 129. 
Where does his superiority come from? Couplet uses probus (good man). Zottoli translates Junzi (君子) with sapiens, the wise man. In Latin sapiens signifies the man who has achieved full rationality, who is really and fully a man because he understands reality and has found the meaning of life. In anthropology the highest level of human evolution has come to be called homo sapiens.

Yet, for Confucius, not all those who belong to the race of homo sapiens are really sapientes. Sapientia in the Latin tradition has a very deep and specific meaning. It can be used to translate the Greek sophia, the love of which is called philo-sophia, the highest target of human life for both Plato and Aristotle. Moreover, Sapientia in the Jewish-Christian tradition is a gift of God, a sharing in God's own almighty omniscience: "the fear of God is the beginning of wisdom" (Prov. 9.10). Thus, the word sapiens for junzi (君子) really stresses the rational dimension of the word, the achievement of perfection through knowledge or enlightenment. Perhaps the simple word used in the unpublished manuscript translation of Michele Ruggieri is the best translation: bonus, 'the good man'. Here the emphasis is more on moral behavior than on knowledge.

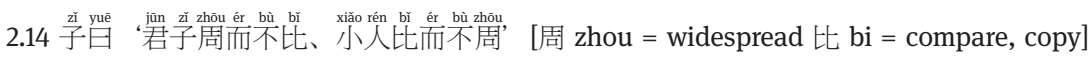

Legge: "The Master said: The superior man is catholic and not partisan. The mean man is partisan and not catholic".

Ruggieri: Idem. Bonus perfectus vir non unius alicuius rei cupiditate ducitur sed ad omnia se potius refert atque accomodat. Improbus vero aliquid tantum spectat; de reliquis non laborat.

Couplet: Confucius ait: Probus atque perfectus vir amplitudine quadam charitatis ac beneficentiae, qua de omnibus mereri desiderat et communem generis hominum conciliationem et consociationem colere ac tueri, universalis est et non particularis. Contra vero improbus ac vilis abiectique animi homo particularis est, privatis affectibus ducitur, amicitiam foeneratur et beneficia sua meritaque privatis emolumentis et commodis seu pretio quodam sordido divendit; adeoque non est universalis.

Noel: Confucii effatum: sapientis erga homines amor est universalis, non particularis; insipientis, particularis, non universalis.

Couvreur: Magister ait: vir sapiens animo complectitur homines universos, non paucos solum unice amat; vulgaris homo paucos unice amat, et non complectitur universos.

Zottoli: Philosophus ait: Sapiens est universalis et non factiosus; vulgaris homo est privati affectus, non universalis benevolentiae homo.

Cheung : Confucius dixit: vir ingenuus omnia amplectitur nec uni parti favet. Vir minutus favet nec omnia amplectitur.

13 Nietzsche (2005-1885) talks about a "super-man" (Übermensch) as the goal of human progress. 


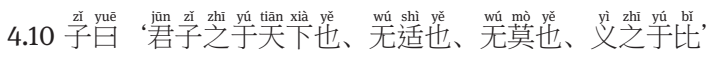

Legge: "The Master said: The superior man, in the world, does not set his mind either for anything, or against anything; what is right he will follow".

Ruggieri: Boni viri quod dux quidam et auriga est ratio; ut nec velle nec nolle habeat, sed totus ex ratione sit aptus.

Couplet: Perfectus vir, seu, verus philosophus in hoc orbe non habet obfirmatum animum ad agendum, neque habet ad non agendum: convenientia cuiusque rei est id quod sequitur.

Noel: Confucii effatum: in quibusvis mundi rebus nec ad agendum, nec ad non agendum omnino se praedefinit sapiens; sed unam ubique aequitatem sectari statuit.

Couvreur: Magister ait: vir sapiens, in imperio regendo, nihil vult pertinaciter, nihil respuit pertinaciter. Aequitas est cui adhaeret.

Zottoli: Philosophus ait: sapiens vir quoad totum imperium, nihil obstinate velle nihil nolle, aequitas est quacum adhaeret.

Cheung: Confucius dixit: ubivis gentium est nihil ingenuo perfecte affirmandum, nec quicquam perfecte abnuendum. Hic se secundum iustitiam metitur.

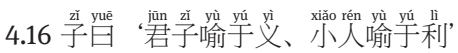

Legge: "The Master said: The mind of the superior man is conversant with righteousness; the mind of the mean man is conversant with gain".

Ruggieri: Bonus ea quaerit quae recta ratione non discrepant; improbus ea potius quae propriae cupiditati collibita fuerint.

Couplet: Confucius ait: vir probus ac vere philosophus valde perspicax est in iis quae sunt rationi consentanea, improbi vero ac homines oculatissimi suis in lucris et commodis, quid e re sua sit, quid contra, acutissime discernunt.

Noel: Sapiens in aequitate, insipiens in utilitate peritus est.

Couvreur: Magister ait: vir studiosus virtutis multum intelligit in iis quae recta sunt; vulgaris homo multum intelligit in iis quae ad utilitatem spectant.

Zottoli: Philosophus ait: sapiens vir est prudens in justitia, vulgaris homo intelligens in lucro.

Cheung: Ingenuus iustitiam intellegit, minutus vero lucrum.

Connected with the definition of 君子, sapiens, we can see some elements describing the character of the superior man. What are for Confucius the characteristics of a 'good man'?

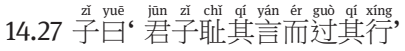

Legge: "The Master said: The superior man is modest in his speech, but exceeds in his actions". 
Ruggieri: Confusius ait: Pudet perfectum virum sua verba factis esse maiora. ${ }^{14}$

Couplet: Sapiens erubescit sua ipsius verba, si quando vincant seu excedant sua ipsius facta.

Noel: Sapiens plus loqui quam agere erubescit.

Couvreur: Magister ait: sapiens vir pudorem servat in suis dictis, et excedit in suis factis, id est, cavet ne jactet dicta quae ipse non faciat, et amplius facit quam dicit aut docet.

Zottoli: Philosophus ait: sapiens modestus suis verbis, at excedens suis actibus.

Cheung: Confucius dixit:ingenuo pudori est si verba gestis praestant.

Humility is considered also in today's China one of the most important virtues, and you might meet people in China who boast of their own humility.

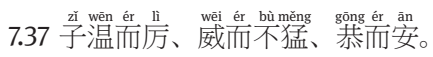

Legge: "The Master was mild, and yet dignified; majestic, and yet not fierce; respectful, and yet easy".

Ruggieri: Confusius ait homo affabilis esse debet sed cum gravitate ac gravis sine crudelitate, urbanitatibusque utens, gaudebit, securusque erit.

Couplet: Confucius (ut testantur eiusdem discipuli) blandus erat, comis, affabilis; et tamen idem venerandus et compositus: gravis erat ac severus ubi res postulabat; idem tamen haudquaquam morosus, asper, truculentus. Officiosus, observans aliorum et reverens; sic tamen ut perquam temperate, suaviter, ac citra molestiam et fastidium.

Noel: Confucius, ut referunt eius discipuli, comitatem cum gravitate, severitatem cum benignitate, magnanimitatem cum modestia singulariter noverat coniungere.

Couvreur: Magister erat comis, sed gravis; severus, sed non asper; ritum perficiens, erat habitu reverenter composito, sed facili.

Zottoli: Confucius comis (elegant) cum gravitate (severity), severus sine asperitate, officiosus (attentive) cum maturitate (maturity).

Cheung: Confucius erat tum mitis tum severus, tum venerandus tum non timendus, tum comis tum tranquillus.

Gravitas is one of the main characteristics of the perfect Roman gentleman, according to Cicero (for example De Senectute 4.10). Comis is the opposite of a "barbarian'. It indicates a man who is educated, elegant, with good taste, but at the same time gentle and affable. Officiosus for 恭 is another word with a particular background, coming from officium, meaning 'duty'. Severitas is the ideal of a

14 Confucius says: "the perfect man is ashamed that his words might be greater than his actions”. 14.27子曰‘君子恥其言而過其行’ 
Roman leader: decisive, strong, seldom smiling - and never to subjects - fair but stern.

\section{Love, virtue (仁 - ren)}

Ren (仁) is one of the most important terms in Chinese moral reflection. It is composed of the character meaning 'man' combined with the character for 'two'. There is no term in English that corresponds exactly to this word. The word itself has different meaning in Confucianism, Buddhism, or Taoism. Therefore, often some English translations keep the transliteration Ren. Hsieh Yiu-wei ${ }^{15}$ tried to combine all the different interpretations given to Jen in Chinese philosophy under six main characteristics: Universality, Permanence, Creativity, Susceptibility, Flexibility, Protectiveness. ${ }^{16}$

It is a word embracing all those moral qualities that should govern one man in his relation with another. "It has sometimes been said that the great merit of Confucianism is its discovery of the ultimate in the relative - in the moral character of human relationship". ${ }^{17}$ The philosopher Cheng Hsuan of the Han period interpreted Ren to mean "the correct relationship between two persons". ${ }^{18}$ This word has received various English translations as 'magnanimity', 'benevolence', 'perfect virtue', 'moral life', 'moral character', 'true manhood', 'compassion', 'human heartedness', 'man-to-manness'. ${ }^{19}$ The variety of the English translations of this term can give some idea of the range of concepts linked to this character trait. Sometimes Ren can be taken also to mean virtue in its entirety, including all kinds of virtues. Derk Bodde, translating the second volume of Fung Yunlan, decided to use "love". ${ }^{20}$ Let us see an example. In 14.28 Confucius says:

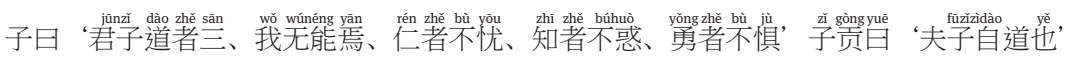

Legge: "The Master said: the way of the superior man is threefold, but I am not equal to it. Virtuous, he is free from anxieties; wise, he is free from perplexities; bold, he is free from fear”. (The main word ren is in the sentence: 仁者不忧 (renzhebuyou) = man of virtue but without anxiety.)

15 Quoted by Chang (1980) 76-77.

16 Chang (1980) 77.

17 Küng/Ching (1989) 68.

18 Chang (1980) 75.

19 See Yi (1967) 152.

20 Fung (1952) II, xvii. 
Ruggieri: Perfecti viri ratio in tribus quam ego perficere non possum potest inesse. Pius est sine tristitia; sapiens est sine dubitatione et fortis est sine metu. Ziconus respiciens sic loquitur: Confucius de se loquitur - i.e. - humiliter.

Couplet: Confucius ait: laus veri sapientis et via seu norma triplex est. At ego proh dolor! Nullam adhuc teneo. Innocentia vitae praeditus rationi ac coelo constanter obtemperat; adeoque non turbatur, quamcumque tandem subeat fortunae vicissitudinem. Prudentia instructus sincerum a pravo, falsum a vero solerter discernit; adeoque non haesitat, nec anceps distrahitur. Denique fortis ac sine metu at singulari quodam praeditus excelsi invictique animi non pertimescit aut pavet.

Noel: Confucii effatum: sapientis perfectio tres virtutes complectitur ast ego ne unam earum huc usque potui consequi: vir sapiens, est pius sine moerore, doctus sine errore, fortis sine timore.

Couvreur: Magister ait: quae sapiens vir exsequitur, tria sunt: e quibus ego ne unum quidem possum: perfectus, non tristatur; prudens, non errat; fortis, non metuit.

Zottoli: Philosophus ait: sapientis ratio triplex; et ego nullam attingo corde, perfectus, non tristatur; prudens, non hallucinatur; fortis, non pavet.

Cheung: Confucius dixit: via ingenue tria habet quae ego consequi nequeo: benevolens non sollicitatur, prudens non fallitur, fortis non metuit.

Couplet uses a very complex sentence: innocentia vitae praeditus rationi ac coelo constanter obtemperat, ("the one who is gifted with integrity of life obeys constantly to reason and to Heaven"). This long phrase translates only the words 仁者: we see how difficult is to express ren (仁) in other languages!

Ruggieri chooses pius, which in Latin has probably as many meaning as ren (仁): dutiful, devout, conscientious, affectionate, tender, kind, patriotic, good, grateful, respectful, loyal. Pius is also one who does his duty to the gods or to the parents or to the teachers or to the country. In this case it also expresses that 'proper relationship' that is the main meaning of 仁 (ren). ${ }^{21}$

Sapiens, perfectus, benevolens are other choices.The general impression is that the Latin translators do not seem to perceive anything in the Chinese word ren different from the classical idea of virtue and goodness. Actually, our modern approach tries always to emphasize differences you cannot really translate that $!$ rather than finding common grounds.

Another example:

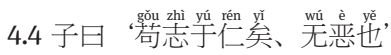

Legge: "The Master said: If the will be set on virtue, there will be no practice of wickedness".

21 Chinese language has no clear distinctions among nouns, adjectives, and verbs. 
Ruggieri: Veritas ita perpetua pietatis est comes ut ubi haec est, abesse illa non possit. Ubi autem et pietas et veritas habitat; peccatum inde exulet necesse est.

Couplet: Confucius ait: si quis serio firmiterque applicet animum ad virtutem, is nihil quod turpe sit aut contrarium rationi committet.

Noel: Confucii effatum: qui pietatem cordisque rectitudinem sequi firmiter statuit, hic potest ab omni crimine se tutari.

Couvreur: Magister ait: vir vere intentus ad virtutem, abstinet malo,

Zottoli: Philosophus ait: vere intentus in probitatem, nihil mali aget.

Cheung: Confucius dixit: diligenter benevolentiam affectare est sine vitiis esse.

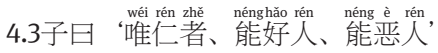

Legge: "The Master said: It is only the (truly) virtuous man, who can love, or who can hate, others".

Ruggieri: Ille tantum et amare novit probos et perditos ac sceleratos odisse, qui hac videlicet pietate pectus ornari.

Couplet: Confucius ait: solus ille qui probus est, tuto potest diligere homines, tuto potest odisse homines.

Noel: Confucii effatum: soli pii ac recti viri possunt alios recte et amare et odisse.

Couvreur: Magister ait: solus vir virtute praeditus potest recte amare homines, recte odisse homines.

Zottoli: Philosophus ait: solum virtute praeditus potest amare alios, potest odisse alios.

Cheung: Confucius dixit: soli benevolentes homines amare aut odisse possunt.

Here we see also virtute praeditus, probus and rectus. Probitas is honesty, the moral rectitude of the Roman gentleman. The probus vir is excellent, upright, honorable, honest, virtuous. Once again, the translation uses the classical idea of virtue and goodness in general.

\section{Decorum and shame (文, 耻 - wen, chi)}

文(wen) is another multifaceted character. Its meaning ranges from 'document' or 'written language' to 'civilization', 'culture', 'civilian activity' (not military), but includes also 'refined', 'elegant', 'cultured'. These meanings are connected: in the Chinese tradition the highest level of civilization is associated with the idea of 'writing'. The meaning of life comes from a life filled with culture, as we said above about 'study'. 
In Latin, 文 (wen) is translated mostly with decorum or decor,-oris. Decorum, too, in Latin has a particular meaning and history. Cicero casts it as one of the main characteristics of a gentleman, basically identifying it with 'honesty'. ${ }^{22}$ It expresses a mixture of moral goodness and proper external behavior, a sense of dignity united with the respect of tradition. In the English translation of Classical Latin texts often the original term decorum is used, since no English word really conveys the same depth. However, in translation from Chinese to English sometimes the word decorum is also used to translate 礼. ${ }^{23}$

Couplet, as usual, is much longer and baroque: cumque viros haberet et literis et armis claros; horum opera tam feliciter attemperavit... ("he had people famous for studies and arms, and followed the deeds of these people”):

Let us see the following examples:

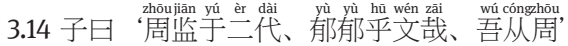

Legge: "The Master said: Châu had the advantage of viewing the two past dynasties. How complete and elegant are its regulations! I follow Châu".

The passage is missing in Ruggieri's manuscript.

Couplet: Ego itaque lubens sequor familiae Chou mores et instituta: maxime quando mihi contigit illa imperante nasci atque aetatem gerere.

Noel: Confucii effatum: cum nostrae imperialis familiae Cheu primi principes Ven Vam, Vu Vam, Cheu Kum perspexissent, quid in duorum priorum imperiorum Hia et Xam legibus et ritibus vel defuisset vel redundasset, ipsi adeo praeclaram regiminis artem instituerunt, ut nihil praestantius, nihil ornatius inveniri posit. Ideo has Imperii Cheu leges tanto studio veneror ac sequor.

Couvreur: Magister ait: Tcheou (regia familia) inspexit (et imitata est) duas regias familias (Hia et Chang, quae praecesserunt). Quantus est decor (rituum Tcheou familiae)! Ego sequor Tcheou (ritus)

Zottoli: Philosophus ait: Tcheou inspexit in duas dynastias: proh quam abundans ejus decorum! ego sequor Tcheou.

Cheung: Confucius dixit: Hereditas Chou est duarum domuum imperialium. Quam litterae florent! Chou faveo.

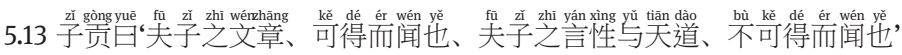

Legge: “Tsze-kung said: the Master’s personal displays of his principles and ordinary descriptions of them may be heard. His discourses about man's nature, and the way of Heaven, cannot be heard".

22 Cic. Off. 1.93.

23 For instance in Lancashire et alii (1985), the translation of Ricci’s 天主实意. See also Ferrero (2004a). 
Ruggieri: Possunt quidem summam illam elegantiam qua Confusii nitet oratio, praeclare omnes cognoscere; at compendiariam illam ac brevem de natura coelestibusque rebus tractationem non item.

Couplet: Aliquando Cucum dixerat: Confucii magistri nostri exteriorem illam compositionem et ornatum seu styli, seu morum et actionum potest quis etiam mediocris ingenii et percipere. At vero haec a Confucio nostro assidue praedicata natura eiusque dictamen caelitus homini inditum, non possunt tamen capi penitusque perspici ne a perspicacibus quoque ingeniis.

Noel: Discipulus Tzu kum, cum forte Confucium de natura et caelo disserentem audivisset, sic coepit loqui: singularem magistri nostri modestiam, gravitatem, facundiam quilibet discipulus potest passim percipere; sed eum de natura, de recta rationis substantia, de caeli via seu agendo ne differentem non licet, nisi rarissime, audire.

Couvreur: Tzeu koung ait: Magistri de cultu et decore (i.e. de corporis habitu et motibus, de urbanitate...) documenta, discipuli omnes possunt assequi ut audiant. Magistri documenta de hominis natura et caeli actione non omnes assequuntur ut audiant: sapientissimi viri scholae institutio non transiiebat gradus, i.e. gradatim procedebat.

Zottoli: Tse kong ait: Magistri concinnum decorum, possum obtinere ut percipiam: at magistri doctrinam de natura coelique lege, non datur percipere.

Cheung: Tzu Kung dixit: magistri studia litterarum nota sunt, sed non eius verba de natura et via caeli.

A very special element in Confucius' tradition is the concept of the sense of shame, which in popular culture is often associated with 'saving face'.

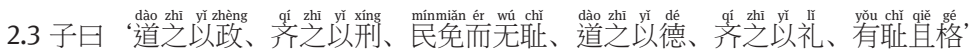

Legge: "The Master said: if the people be led by laws, and uniformity sought to be given them by punishments, they will try to avoid the punishment, but have no sense of shame. 2. If they be led by virtue, and uniformity sought to be given them by the rules of propriety, they will have the sense of shame, and moreover will become good".

Ruggieri: Qui populos legum imperio moderantur, contumaces parant. Propositione coerceant ex hoc enim fiet, ne admissis iam sceleribus, magno cum probro ac dedecore merita de nocentibus poena sumenda sit. Qui virtute ac benignitate cives gubernat, eos ita dirigit nihil ut committant quod pudeat; sed in virtutem studio totis viribus elaborent.

Couplet: Confucius ait: a rege aut gubernatore si dirigantur subditi, atque in officio contineantur per solas leges; qui has tamen non observarint, nihilominus in officio contineantur per terrores atque supplicia: populus tunc quidem servili metu compulsus abstinebit sese a delictis gravioribus; sed profecto more improbi cuiusdam servi, sine pudore scilicet ac vero criminum odio, atque adeo non diu in officio persistet: persistet enim violenter et timore magistro, qui utique malus officii magister est.

Contra vero si regas ac dirigas illos per unam fere virtutem, virtutis ipsemet omnibus exemplum, ad hoc procul dubio se component omnes: et quoniam non est eadem conditio omnium, neque esse par virtus potest; tu siquidem prudentia atque humanitate tuos contineas si mo- 
dereris subditos per sua quemque officia atque ita socies omnes vinciasque, plane fiet ut teneantur ipsi in modo ingenuo quodam pudore metuque filiali ne peccent sed ultro quoque et alacriter ad omnem virtutis laudem contendent atque pervenient.

Noel: Si princeps populos solis et imperiis et poenis coerceat; illi quidem scient poenas evadere, sed nescient vitia erubescere. Contra si princeps populos tum virtutum exemplo dirigat, tum honestatis viribus coerceat; illi et scient vitia erubescere, et virtutes acquirere.

Couvreur: Magister ait: si princeps ducat eum (populum) per leges, et unum faciat eum per poenas, populus abstinebit a culpis, sed carebit pudore. Si ducat eum virtutis suae exemplo, et unum faciat eum moralibus praeceptis, (populus) habebit pudorem, et attinget (rectum).

Zottoli: Philosophus ait: si ducas illum per civiles leges, et componas illum per poenales leges, populus sibi cavebit, at carebit pudore: si ducas illum per virtutem, et contineas illum per ritus, habebit pudorem atque adeo fiet rectus.

In this case also Couplet chooses the same Latin word sine pudore.

Cheung: Confucius dixit: duc per consilia, coerce per poenas, et fieri potest ut populus cohibeatur, sed sine rubore. Duc per virtutem, coerce per ritus, et rubor orietur et diligentes profectus.

In Chinese the word for shame is 耻 (chi). The sense of this shame regulates the behavior of an individual in society. Couvreur and Zottoli translate with this term with pudor, which, in the Roman tradition, expresses the sense of honor, of shame, and of decency. Ruggieri uses dedecor, while others prefer a reference to the blush: erubescere and rubor.

In the Classical world honor was one of the most important values. People were ready to go to war and die for their honor (let's think of Homer's characters or the ideal of Roman heroes in Virgil or Livy). Pudor refers also to proper sexual behavior. The virtue of pudicitia was an ideal presented by Livy, Cicero, Tacitus and others against an excessive relaxation of moral behavior. For the ancient Romans, the loss of pudor led to chaos, anarchy, and loss of social control. It is very interesting to see in Roman history the relation between the sense of shame (pudor) and the precision of the legal system (lex Romana). The more corrupt society became, the more laws were needed (corruptissima re publica plurimae leges, "when the republic is most corrupt, the laws are most numerous," according to Tacitus).

With the advent of Christianity and the influence of the (already Jewish and then Christian) legal tradition of God's Ten Commandments as a main motivation of moral life, 'law' replaced 'honor' as the main tool of social cohesion. The outcome was that in the Western world the 'rule of law' became more important than the 'sense of shame', which was largely relegated to the sphere of private life. Obedience to law(s) also became a sign of moral goodness, while for 
Confucius - and some of earliest Christian texts - the good man does not need external laws to be good.

\section{Heaven and God (天, 神 - tian, shen)}

One of the most heated discussions among early sinologists was over how to translate into Chinese the Christian word "God". The main question was: is there in Chinese a word that means God and can be used by Christianity without misunderstanding and confusion?

Translators across the centuries used four Chinese words. At the beginning, simple transliterations from Latin were used: pa-ti-shih-mo for Baptism (Lat. Baptismus); ma-ti-li-mo-ni-yo for marriage (Lat. Matrimonium); pei-ni-teng-chiya for Confession (Lat. Paenitentia); ya-ni-ma for soul (Lat. Anima), and so on. Thus Deus became 陡斯 (dousi).

Later Jesuits and sinologists employed other three words: 天, 天主, 上帝. ${ }^{24}$ 天 (Tian) means 'Heaven' in general. 天主 (Tianzhu) means 'the Lord of Heaven', 上帝 (Shangdi) was the word used in Chinese antiquity to refer to a higher spirit.

Which word to choose was quite controversial in the first decades of Western sinology, with the debate ranging among the uses of 天, 天主 and 上帝. Pope Clement XI issued the 19 March 1715 Papal bull Ex illa die, which officially condemned the Chinese rites and forbade the use of Tian to signify God. ${ }^{25}$ Finally, 天 主 (Tianzhu) was chosen, while the Protestants, to stress their difference from Catholics, used 上帝 (Shangdi).

The Latin Coelum had a similar fate. In the ancient Roman world it has a meaning very similar to Chinese 天, but with the advent of Christianity became synonymous with God himself. In the Gospel Jesus talks about regnum coelorum, translated in English as 'the Kingdom of God' (see for example Matt. 13 of the Vulgate). For all Christian translators, Coelum was the safest translation of the Chinese 天, because it does not necessarily mean 'God' in the sense of the personal Creator revealed by Jesus.

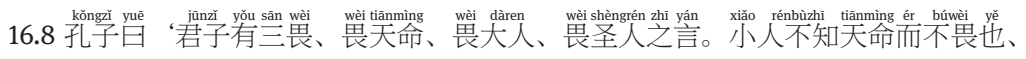

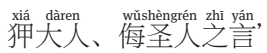

24 Lancashire et alii (1985) 27. The bibliography on this topic is very riche: see, for instance, Kim (2004).

25 Confirmatio et innovatio constitutionis incipientis: ex illa die, Ex typographia Reverendae Camerae Apostolicae, Romae 1742. 
Legge: "Confucius said: there are three things of which the superior man stands in awe. He stands in awe of the ordinances of Heaven. He stands in awe of great men. He stands in awe of the words of sages. 2. The mean man does not know the ordinances of Heaven, and consequently does not stand in awe of them. He is disrespectful to great men. He makes sport of the words of sages".

Ruggieri: Confusius ait: Perfectus vir tres reverentias praestat; reveretur lumen nobis a caelo inditum. Reveretur magnos homines; reveretur verba sanctorum hominum. Humiles vilesque homines lumen naturale extinxerunt, ideo non illud reverentur; parvum faciunt magnos homines; male tractant sanctorum virorum verba.

Couplet: Confucius ait: sapiens ac probus habet tres timores: timet Coeli mandatum, timet magnos viros, timet sanctorum verba.

Noel: Tria sunt, quae sapiens veretur: veretur Caeli legem, veretur illustres viros, veretur sapientum dicta. Contra insipiens, caelestis legis ignarus, illam non veretur, aspernatur illustres viros, ludificatur sapientum dicta.

Couvreur: Confucius ait: sapiens vir habet tria quae veretur. Veretur Coeli mandatum, i.e. legem naturalem quam Coelum indit in cuiusque hominis animo; veretur virtute et dignitate conspicuous viros; veretur sapientissimorum virorum dicta.

Zottoli: Confucius ait: sapiens tria sunt quae veretur; veretur coeli numen, veretur magnos viros, veretur Sanctorum verba. Vulgaris homo non cognoscit coeli numen, adeoque nec veretur: parvifacit magnos viros, ludificatur Sanctorum verba.

Cheung: Ingenuus de tribus metuit: de fato metuit, de magnis hominibus metuit, de sapientium verbis metuit. Minutus, qui nec fatum cognovit nec metuit, magnos homines contemnit et sapientium verba ludibrio habet.

Here we have a variety of terms associated with Caelum: lumen nobis a caelo inditum; Caeli legem; Coeli mandatum and an unusual de fato (Cheung). Zottoli translates 天命 with coeli numen, 'the will of God'. The Latin expression was used in Roman times with the same meaning as the Chinese, as the order of Heaven that the emperor has the power to interpret. Thus in 2.4 (see below) Zottoli translates 天命 (tianming) with Coeli providentia, an example of how translation can “widen the original text” (Bachtin). 命 means 'order, command', while providentia is 'foresight, providence. For Cicero, providentia was one of the main attributes of actual prudence. For Seneca, in his De providentia, it is the Stoic concept of the order of the universe very similar to the Confucian tradition.With Christianity the meaning changed and became synonymous with God's intervention in the world, the act of an almighty God who knows everything and organizes everything for the good of those he loves (Rom. 8:28).

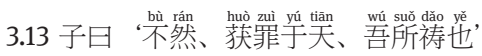

Legge: "The Master said: not so. He who offends against Heaven has none to whom he can pray". 
Ruggieri: [Guansum Chiao quaerenti, in templo ne Nga an Tau idolo sacrificium facere praestaret]; Confusius respondit idolis sacrificandum non est. Si in coelum peccasti: simulacra haec noxiam tibi condonare non poterunt.

Couplet: Sed Confucius haud ignarus quo tenderet superbi hominis iocosa percunctatio, iudicans alienum esse a recta ratione, viroque sapiente et probo indignissimum adulando gratiam alterius aucupari, sic ait: nequaquam sic ut tacite mihi suades, agendum est; nequaquam sequor vulgi morem: quisquis enim peccaverit in coelum, non habet aliud Numen superius a quo peccati veniam deprecetur.

Noel: Cui Confucius, facetiam intelligens: non ita, inquit: unum est Caelum, quod omnes honore et majestate superat; si autem in Caelum peccaveris, nullus est, quem roges, ut te a poena eximat; nimirum nec foci, nec anguli spiritum rogando quidquam proficies.

Couvreur: Magister ait: non probo (blanditias sive in penetralibus sive ad focum adhibitas). Qui (non recte agendo) admittit culpam in Coelum, non habet quem precetur (ut veniam obtineat).

Zottoli: Confucius ait: non ita; committens peccatum in coelum, non habet quem deprecetur.

Cheung: Wang-Sun Chia Confucium rogavit: quid significat verba: blandire deo culinae potius quam deo atrii? Confucius dixit: non ita esse oportet. Caelo enim offenso non esset ubi oraremus.

All the Jesuit interpreters translate this sentence as if Confucius was saying that there is no point making sacrifices to the gods if your behavior is not righteous. In this he sounds more like an Old Testament prophet or even a prefiguration of Matt. 5: "if you present gift to the altar, go first to reconcile with your brothers..."26

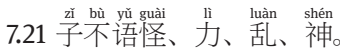

Legge: "The subjects on which the Master did not talk, were extraordinary things, feats of strength, disorder, and spiritual beings".

Ruggieri: Confucius misteriosa ac incredibilia non loquitur; de viribus ac inter principes et reges pugnis bellisque non tractat; nec de spiritibus, qui non videntur.

Couplet: Confucius (uti memorant discipuli) de quattuor rebus non nisi rarissime et quidem brevibus loquebatur. De rebus scilicet exoticis, inusitatis, peregrinis, de monstris, atque prodigiis. De factionibus atque dissidiis et perturbationibus publicis. Denique de spiritibus, quod eorum virtus, efficacitas, natura usque adeo subtilis ac sublimis sit et ab humano sensu remota, ut de illa debite loqui sit periculum.

Noel: Quattuor erant, quae vix loquebatur Confucius: novitatum portenta, virium ostentationes, seditionum tumultus, spirituum naturam.

26 About the attempts to present Confucius as a suitable preparation for Christianity, see Rule (1986). 
Couvreur: Magister non loquebatur de insolitis rebus, de violentis facinoribus, de turbationis, de spiritibus.

Zottoli: Philosophus non loquebatur de monstris, violentiis, turbationibus et spiritibus.

Cheung: Confucius non de prodigiis, vi, tumultibus et deis locutus est.

Here we find the word 神 (shen), that mean 'spirit' or 'god'. There is a difference in Confucius' mind between 'Heaven' (天) and 'spirit' (神), so all translations keep it by using spiritus.

\section{Wisdom and virtue 道 (dao)}

The Latin translation of the word Dao (道) is again a significant witness to the richness and challenges of the meeting between these two languages.

“The word Dao (道) is one of the most important terms in Chinese philosophy"27. The original meaning of Dao is 'road' or 'way'. Beginning with this primary meaning, it assumed, already in ancient times, a metaphorical significance, as the 'way of man', that is, human morality, conduct, or truth. Its original meaning was restricted to human affairs, social morality, but already in pre-Confucian China the word Dao had become implicitly a symbol of the standard life of the perfect man..$^{28}$

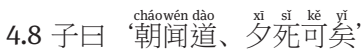

Legge: "The Master said: if a man in the morning hears the right way, he may die in the evening without regret”.

Ruggieri: Mane quae rationi sint consentanea accipies quod si paucis post horis forte una cum die ipso tibi contingat occumbere; praestare tecum agetur.

Couplet: Mane qui audiverit legem, vesperi mori potest. Nec erit quod vixisse poeniteat aut taedeat mori.

Noel: Confucii effatum: qui rectam vivendi disciplinam mane didicit, vespere potest tranquille mori.

Couvreur: Magister ait: qui mane intellexit rectam agendi rationem, vespere mori decet (potest mori contentus).

Zottoli: Philosophus ait: si mane acceperis sapientiam, vespere mori licebit.

Cheung: Confucius dixit: audire mane viam praevalere est posse sine desiderio nocte mori.

27 Fung (1952) I, 177.

28 Chang (1963) 25. 
Because of the complexity of the term, the translators employ a variety of Latin expressions: ratio, lex, recta vivendi disciplina, recta agendi ratio, sapientia, and also via. Ratio in Latin refers to right reason, the order of the mind, or also the order of the universe. Lex (Couplet) hearkens the Jewish legal background of Christian thought, because a 'law' implies a lawgiver. Disciplina belongs to the semantic group associated in general with study and the search for wisdom. Via (Cheung) is more similar in meaning to the Chinese word, but in the Western tradition the expression ego sum Via was used by Jesus, and thus the Jesuits would not employ it for the Chinese 'Dao'.

In the following examples we can see an even richer variety. 邦有道 (bang you dao) means 'when the country had Dao'. It is translated as sedato regno, probitas, bono regimine florebat", regno recte composito, ordo, and again via.

5.21 子吂怕

Legge: "The Master said: when good order prevailed in his country, Ning Wû acted the part of a wise man. When his country was in disorder, he acted the part of a stupid man. Others may equal his wisdom, but they cannot equal his stupidity”.

Ruggieri: Nicuentius sedato regno sapientissime se magistratu non abdicat; eo vero ardente bellis quasi rerum imperitus publici muneris administrationem non deserit. Eius quidem sapientia cum aliis potest esse communis sed ad ignorantiam illam non omnium est adspirare.

Couplet: Confucius ait: Nim Vu cu praefectus regni Guei, quando in regno seu domo regia viget probitas, prudens audit apud omnes. Si quando autem regnum est sine lege ac probitate sic ut perturbari incipiat ac periclitari; ipse tempestati subducens sese, sic latitat, ut a vulgi oculis remotus.

Noel: Confucii effatum: primarius olim Regni Gui praefectus Nin cognomen Vu, dum regnum bono regimine florebat, singularem suam sapientiam doctissime prodebat; dum malo squalebat, quamvis omnis regni negotia clam sollicitaret, se tamen rudem et ignarum palam simulabat. Illa quidem eius docta sapientia potest adhuc imitatione aequari; sed haec eius sapiens inscitia omnino non potest.

Couvreur: Magister ait: Gning Ou tzeu regno recte composito, prudens fuit; regno non recte composito, imprudens (visus est). Eius prudentia potest attingi (i.e. aequari ab aliis; eius imprudentia non potest attingi (nemo potest eius laudabilem imprudentiam perfecte imitari).

Zottoli: Philosophus ait: toparcha Ning ou tse, regno habente ordinem tunc sapivit; regno amittente ordinem, tunc insanivit: ejus sapientia potest attingi, ejus insipientia non potest attingi.

Cheung: Confucius dixit: Ning Wu Tzu erat sapiens cum via in civitate floreret, sed hebes cum via in civitate non floreret. Sapientia eius pares habebat, sed eius animi hebetatio pares non habebat.

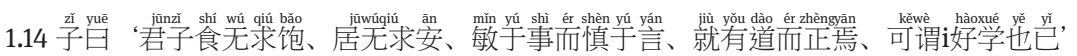


Legge: "The Master said: he who aims to be a man of complete virtue, in his food does not seek to gratify his appetite, nor in his dwelling place does he seek the appliances of ease; he is earnest in what he is doing, and careful in his speech; he frequents the company of men of principle that he may be rectified:- such a person may be said indeed to love to learn".

Ruggieri: Qui virtutis iter addiscit; caducas fluxasque res nihil facit; torporem vitat, rebus non indormit suis; cogitata loquitur, erit facilis ac sine errore profectus; dicique poterit salutaris doctrinae studiosus.

“就有道而正” means the person who has Dao, Ruggieri uses a complex: Qui virtutis iter addiscit.

Couplet: Confucius ait: in quolibet quamvis ignobili et parvo, exempli gratia, decem nec amplius, domorum pago, utique dantur aliqui synceri homines ac veraces (qualis et ipse sum) proprio quodam natura beneficio tales. At non dantur aeque ut ego amantes discere et proficere.

Noel: Qui nec in cibo saturitatem, nec in habitatione commoditatem quaerit, solers in negotiis, cautus in verbis, frequentandi sapientes avidus, hic potest vere dici sapientiae alumnus.

Couvreur: Vir studiosus virtutis qui comedens non quaerit saturitatem, qui habitans non quaerit commoda, qui est diligens in negotiis et circumspectus in verbis, qui adit praeditos virtute (viros) et dirigitur ab eis, dicendus est amans discendi.

Zottoli: Philosophus ait: sapiens qui vescendo non quaerit saturitatem, in mansione non quaerit commoda, est impiger in negotiis et circumspectus in verbis, adit praeditos virtute ut dirigatur, poterit dici amare sapientiae studium.

Cheung: Confucius dixitù: vir ingenuus non gulae deditus est, non vitam delicatam appetit, sed in negotiis alacer et in sermone prudens est, dum optimorum moribus rectis studet. Licet eum iudices studiis deditum esse.

Here again we see how the Latin words grasp the heart of the Confucian tradition. Beginning from the time of Matteo Ricci, all sinologists agreed on the priority of ethics over metaphysics in Chinese tradition. Moreover, in the sentence above there is evident similarity between Confucianism and Stoicism, since both claim that there is an order of Heaven to which a morally righteous man must strive to conform.

\section{Heart (心 - xin)}

First of all let us examine Confucius' famous passage about the various ages of a man. It offers us a synthesis of the beauty of words between Chinese and Latin. Here the important word xue (学) is translated as scientia, from the root scio, which means 'to know'. Scientia in the classical world consisted in much 
more than experiments and laboratory research. According to the classical tradition, scientia represented the summit of intellectual achievement. Different from the meaning of 'science' in our day, with its emphasis on experiments and measurement, Aristotelian science aimed at a loftier ideal: to find universal truths, which are necessary and cannot be otherwise". ${ }^{29}$ Metaphysics was the highest science in antiquity.

天命 (tianming) becomes coeli providentia, the plan of Heaven, that in some way easily fits into the Christian tradition of an Almighty God who takes care of human events. 心(xin) is cor (heart), a word that in any language implies much more than a muscular organ. In this case it is the source and origin of the will (desidero). Also Couplet translates: sequebar quod cor meum appetebat ("I was following the desires of my heart").

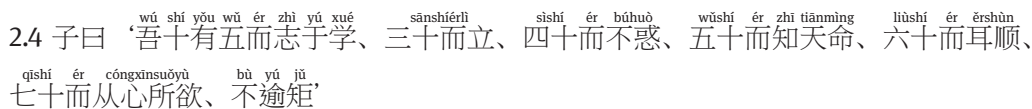

Legge: "The Master said: At fifteen, I had my mind bent on learning. 2. "At thirty, I stood firm. 3. "At forty, I had no doubts. 4. "At fifty, I knew the decrees of Heaven. 5. "At sixty, my ear was an obedient organ for the reception of truth. 6. "At seventy, I could follow what my heart desired, without transgressing what was right".

Ruggieri: Ego quindecim natus annos ad virtutis iter addiscendum mentem animumque converti. Trigesimum agens annum callebam. Decennio maiori nihil omnino erat quod mihi dubium videretur aut obscurum. Decem post annis caeli rationem penitus cognoveram. Decennio item post quidquid esset propositum nullo sumpto ad cogitandum spatio intelligebam. Aetate denique iam devexa septuagesimo vitae anno sine ulla difficultate cuncta ego praescripto rationis suaviter agebam.

Couplet: Annos triginta natus iam constiti: eas inquam radices egeram ut consisterem firmus in suscepto virtutum sapientiaeque studio, neque res ulla extra me posita avocare me ab illo posset. Quadragenarius iam non haesitabam amplius: evanuerant dubiorum nubila, connaturales enim rerum convenientias habebam perspectas et quid singulis inesset perfectionis vel imperfectionis, intelligebam. Quinquagenarius protinus cognovit coeli providentiam atque mandatum et suam rerum singulis a coelo inditam esse naturam, vim, rationem; cuius adeo naturae perscrutabar ipse perfectionem ac subtilitatem; indagabam quoque originem et quae tandem illius esset causa, intelligebam. Sexagenario mihi iam aures erant faciles et secundae, expeditus scilicet et exercitationibus excultus animus, optimisque praeceptis et disciplinis imbutus, sic ut facile clareque perciperem quidquid alii vel disputarent, vel ipse legerem.

Ad extremum septuagenarius longae meditationis victoriaeque mei ipsius beneficio sequebar quod cor meum appetebat; nec tamen excedebam regulam, seu terminus transiliebam honestatis rectaeque rationis, cui iam sine lucta molestiave appetitus meus obtemperabat.

29 Wallace (1999) 17. 
Noel: Confucius senex sic de se ipso aiebat: vix ego quindecim aetatis annos attigeram, cum mox statui sapientiae disciplinis vacare. Annos natus 30 iam totus in illis eram stabilitus, nec ulla mundi res animum a proposito dimovere poterat. Annos natus 40 totam honestatis scientiam naturalesque rerum causas sine haesitatione penetrabam. Quinquagenarius comprehendi Caeli legem, admirabilemque eius cursum. Sexagenarius longo iam usu assuetus sapientiae disciplinis, ita nunc facilis eram in illis penetrandis, ut quidquid aures exciperent, mox mens sine labore caperet. Septuagenarius denique, sequendo vel unum cordis mei impulsum, nulla in re honestatis leges pene transgrediebar.

Couvreur: Magister ait: ego quindecimo (aetatis anno) intendi animum ad sapientiae studium; trigesimo, firmus constabam (constanter, servabam sapientiae leges); quadragesimo, iam nihil dubitabam (mihi nihil obscurum erat in via virtutis); quinquagesimo, noveram Coeli decreta; sexagesimo, auris obsecundabat (audita, etsi non cogitarem, intelligebam); septuagesimo, prosequebar quod animus cupiebat, quin transgrederer normam.

Zottoli: Philosophus ait: ego decem et quinque natus, tunc animum applicavi ad magnam scientiam: trigesimo anno, tunc firmus constiti; quadragesimo, jam non haesitabam; quinquagesimo, tunc novi coeli providentiam; sexagesimo, auris facilis erat ad intelligendum: septuagesimo, tunc sequebar quod cor desiderabat quin transgrederer regulam.

Cheung: Confucius dixit quindecim annos natus eruditionem affectavi. Triginta annos natus nullis fallaciis iam obnoxious eram. Quinquaginta annos natus sciebam quid de me fieret. Sexaginta annos natus veritatem agnovi in omnibus quae audivi. Septuaginta annos natus animi desideria sine peccato sequi poteram.

\section{To transmit (述 - shu)}

This is a Confucian teaching that marks a visible difference between East Asia and the West. The Greek philosopher Socrates was proud to challenge the old traditions. The Judeo-Christian teaching reveals the creative power of God and consequently the goodness of creativity. Socrates and the Bible influenced and changed Western culture by spreading a positive attitude towards 'creativity' and creation.

Confucius, on the opposite, was proud of 'transmitting' rather than 'creating': 述而不作 (shu er bu zuo, 'I transmit, I do not create'). Basically, this sentence means that Confucius wants to present the teachings of the ancients without adding anything different or changing them. 述 (shu) can be 'to report', but also 'to comment'.

Ruggieri chooses colligere, Couplet uses praeco and relator. Ego refero, employed by Noel, calls to mind the common expression: relata refero ('I report what has been reported'). Couver, Zottoli, Cheung, all use the Latin refero, which means 'to carry something back', and is really the opposite of a creative movement forward. 
The second part of the sentence is about respecting the ancients. Most of the translators who use Latin translate 信 (xin) with Credo. This is a particular strong word in the Western tradition, because of the deep influence of Christianity. Credo with the accusative case (宾格) means 'to believe something'; credo followed by the preposition in and the accusative expresses a movement of the will towards believing. In the Christian tradition this second form is used for believing in God as a personal relationship, an act that requires an assent of the will: Credo in unum Deum, 'I believe in one God'.

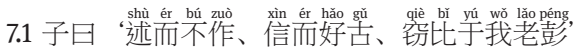

Legge: "The Master said: a transmitter and not a maker, believing in and loving the ancients, I venture to compare myself with our old P'ang”.

There are various hypotheses on who this P'ang is. Perhaps Lao Tze?

Ruggieri: Confucius ait: colligere aut non ipsemet facere, credere et antiquitate gaudere comparor ego Laupono [in Chinese is Lau Peng].

Couplet: Confucius ait: praeco sum, seu relator et non auctor doctrinae, quam palam facio. Credo et amo antiquitatem, ex qua studiose suffuror et excerpo quae ad rem meam sunt; imitatus in me ipso famosum illum senem Pum; quippe qui prior veterum monimenta simili conatu, tradidit posteritati.

Noel: Confucius agens de variis suis elucubrationibus sic aiebat: ego refero priscorum doctrinam, non hanc ego inveni; priscorum enim doctrinae et multum fidei do, et multum ea delector. Atque in hoc dilectissimum nostrum Lao Pum, olim imperante familia Lao, primarium praefectum, ego imitor.

Couvreur: Magister ait: refero (antiqua), et non nova excogito. Credo et amanter adhaereo antiquis, immerito (i.e. licet indignus) me assimilans nostro veteri Peng.

Zottoli: Philosophus ait: refero et non creo; credo et amo antiquitatem, mihi sumens assimilari cum meo Lao p'ong.

Cheung: Confucius dixit: referre nec fingere, credere et deditum esse temporibus antiquis. Permitte ut me cum Lao Peng conferam.

\section{The rectification of the names (正名 - zhengming)}

The 'rectification of the names' is another characteristic of Confucian teaching. For Confucius the social disorder of his times was the consequence of the lack of a clear teaching on the value and meaning of Ren (仁), proper relationship between human beings, and in general lack of clarity on proper social order. He believed that the only way to restore that order would be to arrange social life 
according to Propriety, or Rites, so that the Emperor would clearly know what a good Emperor should do, the nobles what nobles should do, the ministers what ministers should do, the common people what common people should do. This theory is called by Confucius “the Rectification of the Names" (正名) and is of the "utmost importance". 30

So in Dialogues 13.3 the first rule to govern well is described as 正名 (zhengming).

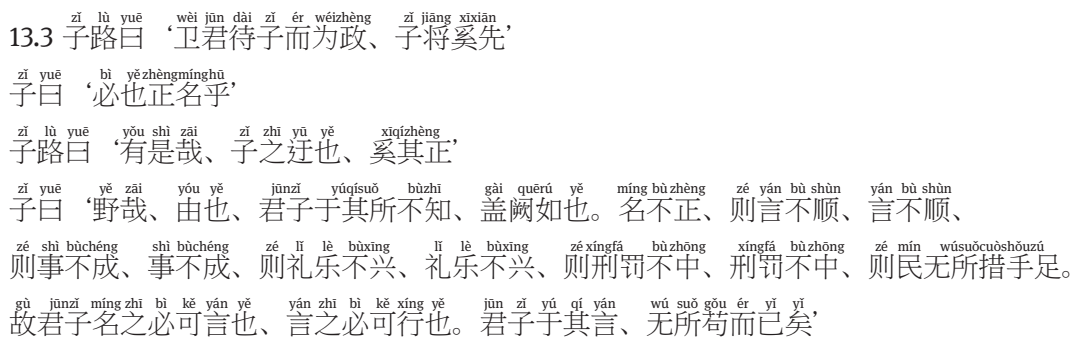

Legge: "Tsze-lû said: the ruler of Wei has been waiting for you, in order for you to administer the government. What will you consider the first thing to be done? 2. The Master replied: what is necessary is to rectify names. 3. So! indeed! said Tsze-lû. You are wide off the mark! Why must there be such rectification? 4. The Master said: how uncultivated you are, Yû! A superior man, in regard to what he does not know, shows a cautious reserve. 5. If names are not correct, language is not in accordance with the truth of things. If language is not in accordance with the truth of things, affairs cannot be carried on to success. 6. When affairs cannot be carried on to success, proprieties and music will not flourish. When proprieties and music do not flourish, punishments will not be properly awarded. When punishments are not properly awarded, the people do not know how to move hand or foot. 7. Therefore a superior man considers it necessary that the names he uses may be spoken appropriately, and also that what he speaks may be carried out appropriately. What the superior man requires is just that in his words there may be nothing incorrect".

\section{Lest us see the various Latin translations.}

Ruggieri: Zilus ait: "Guei regni rex te expectat ut gubernationem exerceas, tu quod primum facias". Confusius ait: "[...] nomen rectum faciam, non nomen proprium, sed status et muneris". Zilus ait: "Ita in animo habes! Hoc non est ad propositum, quod tu illud rectificas?” Confusius ait: "Silvestris homo est Zilus, perfectus vir ea quae nescit, quasi dubius deponit, nescias enim quod nomine non recte imposito verbis tuis non obsequuntur, si verbis non exequentur, res negociaque ad exitum produci nequeunt, si res negociaque non proficiunt, ordines et concordia non erigentur; humanitatibus, ordines et amicitia non erecti, castigationes et poenae non recte infligentur. Castigationibus et poenis non recte inflictis, populus quidem locum non habebit, ubi tuto manus pedesque ponat. Quare perfecti viri nomen oportet dicere,

30 Fung (1952) I, 59. 
dicto oportet hinc conformia agere perfectus vir, non exterius solum habere id quod vocatur". ${ }^{31}$

Couplet: $\mathrm{Cu}$ Lu verba magistri non satis mature expendens quasi illa hic et nunc minus ad rem facerent, parum considerate, estne, inquit, hoc ita, ut ais? Tu magister, ut mihi quidem videris, abes hic longe a vero. Quorsum ista, quaeso, tam supervacanea nominis reformatio, quando sunt alia longe maioris momenti quae hoc statu rerum ac temporum potius videntur tractanda? Confucius tam praecipiti responso suboffensus, vah! Inquit, quam rudis et agrestis es, mi yeu! Vir sapiens in iis quae necdum probe percepit, certe haesitans instar est ac subdubitans; nec temere quod in mentem venit, effutit illico. Audi nunc igitur quid paucis verbis significare voluerim: si nomen ipsum principis non sit rectum, nec eiusmodi, quod ei iure competat; adeoque si in ipsa quasi fronte hominis resplendeat mendacium tum profecto sermones ac mandata haudquaquam secundis auribus et animis; tum procul dubio publicae res et negotia nequaquam perficientur.

Noel: Cui Confucius: numquid, id primum sollicitandum est, ut vera nominis appellatio, quae nunc perturbatur, statim reparetur? Mox reponit Tsu lu: enimvero id magni interest? Pace tua, magister; dicere liceat: haec mens longe a rei cardine abest. Ad quid iuvat illa veri nominis reparatio? Tum acriter eum arguens Confucius: incultus, inquit, et rudis es vir, mi Chum $Y e u$, insulsa semper effutis. Sapiens in iis, quae non intelligit, dubitare saltem novit. Nunc ergo rem accipe. Si vera nominis appellatio non reparatur, verba in tabulis publicis ac iustis non erunt recta; si verba non sint recta, negotia non erunt perfecta; si negotia non sint perfecta, seu non rite perficiantur, rituum ac musicae leges non vigebunt; si rituum ac musicae leges, utpote ad disponenda negotia et ad coniungendos animos accomodatae, non vigeant; poenae in plectendis delictis non erunt aequae; si poena in plectendis delictis non sint aeque, populi non habebunt, in quo tuti pedem figant, nec ad quid secure manum extendant. Quocirca sapiens, ut aliquid nominet, debet videre, an vere isto nomine appellari possit? Ut loquatur, debet videre, an verba sua vere possint opere compleri? Hinc sapiens, ne quid temere loquatur, diligentissime vigilat.

Couvreur: Si nomina non sunt recta (cum rebus non conveniant), sermo non sibi constat (secum pugnat). Sermone non sibi constante, res non perficiuntur. Rebus non perfectis, officia et harmonia non vigent. Officiis et harmonia non vigentibus, supplicia et poenae non quadrant culpis. Suppliciis et poenis non quadrantibus, populus non habet ubi tuto ponat manus et pedes (ubique timet ne immeritus plectatur).

Zottoli: Tse Lou ait: Wei princeps expectat magistrum, ut fungaris magistratu: magister quid prius praestiturus? Confucius respondit: quod potissimum, nonne reformare appellationem? Tse Ion exclamavit: estne ita? magister digreditur; quorsum haec reformatio? Confucius respondit quam rusticus iste Yeou! Sapiens in iis, qum ipse necdum perceperit, quippe omittentis instar. Si titulus non sit rectus, tunc appellatio non probatur; si appellatio non probetur, tunc res non perficientur; si res non perficiantur, tunc officia et harmonia non florebunt; si officia et harmonia non floreant, tunc supplicia et poenae non quadrabunt; si supplicia et po-

31 13.3 路曰“衛君待子而為政、子將奚先” 子曰“必也正名乎” 子路曰“有是哉、子之迂也、奚其 正’ 子曰“野哉、由也、君子於其所不知、蓋關如也。名不正、則言不順、言不順、則事不成、 事不成、則禮樂不興、禮樂不興、則刑罰不中、刑罰不中、則民無所措手足。故君子名之必可 言也、言之必可行也。君子於其言、無所苟而已矣'. 
enae non quadrent, tunc populus non habet ubi ponat manus et pedes. Ideo sapiens princeps quod nominat, certe decebit denominari; et quod denominat, certe licebit peragi: sapiens princeps in suis appellationibus nihil habet quod temere sit, idque totum est.

Cheung: Tzu Lu dixit: si dominus Wei magistro meo dignitatem offerat, unde incipiat magister meus? Confucius dixit ab institutis praescriptis. Tzu Lu dixit si hoc ita se habet, magister circumagitur! Cur instituta praescripta? Confucius dixit Yu quam rudis es. Ingenuus vitat quae ignorant. Institutis non decenter praescriptis, ea quae dicuntur non accipiuntur; dictis non acceptis, nil perficitur, nulla re perfecta, ritus et musica non florent, poenae et supplicia non servantur, poenis et suppliciis non servatis, cives haerent. Itaque institutis praescriptis ingenuo licet eloqui et quod eloquitur ad exitum perduci potest.quae ingenuus loquitur seria sunt.

Ruggieri explains first of all the meaning of 'name': nomen rectum faciam, non nomen proprium, sed status et muneris. To name rightly means to clarify status et munus, social condition and official duties.

Couplet uses nominis reformatio and Zottoli chooses reformare appellationem. Reformare is a powerful word in Western tradition. It means 'to remold new', 'to transform', 'to reform'. We can think, for example, of the ancient Christian motto Ecclesia semper reformanda ('the Church must always reform') or the movement of Martin Luther that was called 'the Reformation'. Noel chooses appellatio [...] statim reparetur. Couvreur prefers nomina recta.

The Confucian theory of the 'Rectification of the names' is particularly significant in this time and age, when truth and fake news clash daily, competing for attention.

\section{Filial piety (孝 - xiao)}

孝 (xiao) means 'to respect' (as a verb or a noun, in Chinese grammar there is no difference between the two). It is mostly used for parents and authorities. It is one of the main Chinese virtues. For Confucius it is one of the foundations of the proper order of society. It corresponds to the pietas of the Classical Roman tradition. Pietas was one of the chief virtues with the double meaning of 'sense of religious duty' (pietas erga deos) and 'filial piety' (pietas erga parentes). In Virgil's Aeneid, pietas is the main virtue of the hero Aeneas. It goes beyond obedience to natural parents and includes in general a sense of respect for authorities and ancestors. The emperor Augustus and then his successor Tiberius made pietas one of main elements of their political and religious shaping of the Roman Empire. The English language accepted the Latin word pietas, making it into 'piety', carrying a more religious meaning. 


\section{2 有子帒 yuē “其为人任én yě xiào dì

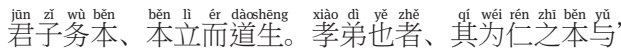

Legge: "The philosopher Yû said: they are few who, being filial and fraternal, are fond of offending against their superiors. There have been none, who, not liking to offend against their superiors, have been fond of stirring up confusion. 2. The superior man bends his attention to what is radical. That being established, all practical courses naturally grow up. Filial piety and fraternal submission! - are they not the root of all benevolent actions?"

Ruggieri: Qui parentes, maioresque colunt, ab eis praeceptis ne transversum quidem umquam audent discedere quod si eorum qui praesunt (praecepta non migrent). Praecepta non migrent: incredibile est eos seditionibus dedecorisque rebus delectari. Perfectionem in omni virtutis genere cupienti in fundamentum ac principia incumbendum est; ea si teneat nihil est quod eum ab instituta virtutis via removeat (?). Propter ea quoque obtemperare parentibus ac maiores vereri, duae res sunt e quibus tamquam e fontibus caritas in proximum proficisci scitur.

Couplet: Discipulus Yeu cu ait: quempiam esse sive dari hominem qui domi quidem obtemperet parentibus et debitis obsequiis officisque prosequatur maiores natu et tamen foris gaudeat adversari legitimis magistratibus profecto rarum hoc est atque inusitatum. Rursum non gaudere quempiam adversari, magistratibus et eundem tamen gaudere seditiones ac turbas excitare et perturbare rempublicam adhuc quidem non accidit seu visum est et auditum quidpiam huiusmodi.

Noel: Yeu iu confucii discipuli effatum: parentum et fratrum natu maiorum cultores, qui ament superiores offendere, vix uspiam reperias; non amantes autem superiores offendere qui ament turbam excitare, hos nuspiam sane reperies. Vir sapiens quod in omnibus spectat, est recte vivendi principium, ex hoc posito principio mox omnis vitae honestas ultro exurgit. Debita vero erga parentes et fratres natu maiores observantia, numquid vere est omnis pietatis principium?

Couvreur: Iou philosophus ait: qui, licet sint ii homines qui colant parentes et observent maiores (aetate aut gradu), tamen ament resistere superioribus, pauci sunt. Qui etsi non amet resistere superioribus, tamen amet excitare turbationem, nondum fuit. Vir sapiens operam dat radici (seu basi virtutis); radice stante, iam virtus oritur. Pietas in parentes et observantia in maiores sunt perfectae virtutis radix.

Zottoli: Yeou tse ait: sic facti homines, qui parentes colant fratresque majores, et tamen ament se opponere superioribus, rari sunt: at qui non ament repugnare superioribus, et tamen ament facere seditionem, nondum ii extiterunt. Sapiens intendit rei fundamento; fundamento constituto, rei ratio enascitur: illa observantia in parentes et fratres, annon ipsa est exercendae pietatis fundamentum?

Cheung: Yu tzu dixit: raro velit pietate filiorum et amore fraterno praeditus sibi praepositos offendere. Nec exstitit quisquam turbulentus quin sibi praepositos offendere vellet. Vir ingenuus quasi radices nutrit. Quibus stabilitis via crescit. Nonne filiorum pietas et amor fraternus radices benevolentiae sunt?

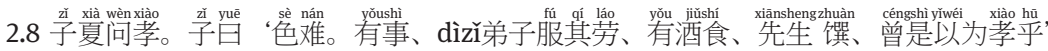


Legge: "Tsze-hsiâ asked what filial piety was. The Master said, "The difficulty is with the countenance. If, when their elders have any troublesome affairs, the young take the toil of them, and if, when the young have wine and food, they set them before their elders, is this to be considered filial piety?"

Ruggieri: Tisbiano de eadem in parentes observantia et cultu interroganti Confusius respondit: in frontis serenitate vultusque hilaritate negotii satis est. Etenim parentibus aerumnosis adversaque afflictis fortuna rebus sustentanda vita necessariis spem ferre (?); idne parentes est colere ac vereri?

Couplet: Discipulus Cu Hia similiter quaestionem instituit de obedientia filiali. Confucius respondet: oris alacritas, sive constans alacritas illa filialis oboedientiae quae adeo in ipsa fronte totoque ore amantis ac reverentis filii reluceat, difficilis est illa quidem, sed profecto nota prope certa vere germanaeque virtutis. Obsequia quippe domestica praestare filii vel inviti atque inoboedientes possunt: uti cum domi quidpiam est faciendum fratres natu minores ac filii familias utique subeunt maiorum loco id quod laboriosum est: rursus cum suppetunt vina et dapes, tunc procul dubio tam parentibus quam fratribus natu maioribus natu minores officiose ministrant epulas; sed hi an idcirco statim censeantur obedientes esse? Enimvero si non haec prompte, constanter et cum alacritate quadam animi corporisque praestiterint, oboedientiae verae nomen ac numeros haudquaquam impleverint.

Noel: Discipulus Tsu Hia quaesiit ex Confucio, quomodo filius Parentes colere deberet? Cui Confucius: quod ego, inquit, in colendis parentibus maxime difficile censeo, est frontis serenitas. Cum parentes aut fratres natu maiores habent aliquid gerendum; si filius, aut frater natu minor pro illis laborem istum subeat: sive cum filius aut frater natu minor cibo et potu affluit, si parentes aut fratres natu maiores laute tractet: credisne hoc suppetere, ut ille dicatur parentes colere? Haec enim - addit interpres - ficto animo fieri possunt; sola frontis serenitas fingi non potest; ideoque difficillima.

Couvreur: Tzeu Hia interrogavit de pietate filiali. Magister ait: species (pietatis filialis) difficile induitur (id est, pietas filialis specie decipere difficillimum est). Occurrentibus negotiis, si fratres natu minores et fili subeant illorum (fratrum natu maiorum et parentum) laborem; habitis vino et cibo, si maiores natu (fratres et parentes) alantur; iam haec est ne censenda pietas? (non sufficit ut quis adiuvet et alat natu maiores, sed insuper necesse est ut eos ex animo diligat).

Zottoli: Tse hia quesivit de pietate filiali. Philosophus ait: oris alacritas, difficilis; quod si habeant negotia, et juniores puerique subeant illorum laborem, iisque habentibus potum et cibum majores natu alimententur, an vero hoc reputabitur pietas filialis?

Cheung: Tzu Hsia dixit: vultus argutus est. Iuvenes onus in laborando sustinent, et seniores ius habent cibum et vinum ante alios eligendi. Sed hocne potest filiorum pietas esse credi?

\section{Rite (礼 - Li)}

To convey properly and express the original meaning of $\mathrm{x}^{\mathrm{l}}(\mathrm{Li})$ is a difficult task. For Herbert Fingarette the communitarian perspective of the Confucian morality 
embodied in the concept of $L i$ (礼, 'propriety') is an interesting alternative to a certain Western liberalist conception of a fully autonomous individual making free choices in complete isolation. ${ }^{32}$ According to Fingarette, Confucianism has developed an original way of investigating how a person thinks, moves and lives reflectively, deliberately, and freely, in the sense of 'not forcedly' and 'spontaneously'. A person is born as 'raw material' into an historical context. The process of learning the code of propriety is "the process of getting acclimated to the sort of conceptual framework which enables him/her to live, move and think as a fully human being".33

"The image of the Holy Rite as a metaphor of human existence brings foremost to our attention the dimension of the holy in human existence. [...] Human life in its entirety finally appears as one vast, spontaneous and holy rite: the community of man." ${ }^{34}$ This means that the virtuous person, in order to reach his/her highest excellence (仁, Ren), should not follow every spontaneous expression of man's nature but should blend them with the proper social form, the rites (礼, $L i$ ). These come from Heaven through the mediation of Tao and social life and are not simply innate, or natural. ${ }^{35}$

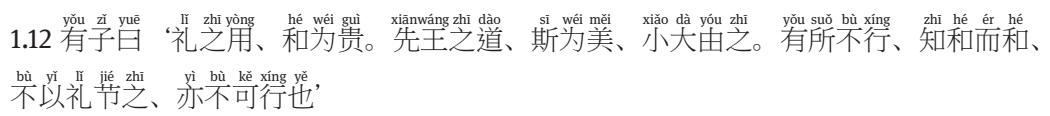

Legge: "The philosopher Yû said: in practicing the rules of propriety, a natural ease is to be prized. In the ways prescribed by the ancient kings, this is the excellent quality, and in things small and great we follow them. 2. Yet it is not to be observed in all cases. If one, knowing how such ease should be prized, manifests it, without regulating it by the rules of propriety, this likewise is not to be done".

Ruggieri: Yeusius: noli ab ingenuitate amorem concordiamque dishabere. Talis enim erat priscorum regum benignitas, quae tum in maximis tum in minimis rebus ex animorum coniunctione manabat. Qui id quod praestat debet, ingenui hominis officium deserit; humanitatem tantumodo retinet. Atqui humanitas ab ingenuitate seiungenda non est.

Couplet: Discipulus Yeu Cu ait: sicut toleranda non est iuris officique violatio, sic in officiorum usu et dum ius aliquod exigitur, placabilitas, moderatio et longanimitas obtinent primum locum. Ex priscorum quidem regum sententia atque instituto in huiusmodi moderatione atque humanitate constituebatur omnis decor atque venustas officiorum et quascunque tractabant illi res minores maioresve, omnes inde procedebant: omnia omnino tam prudenti atque amabili suavitate condiebant ac temperabant, adeoque ad optatum quoque finem feliciter perducebant.

32 See Fingarette (1998) and Lee (1994).

33 Lee (1994) 50.

34 Fingarette (1998) 17.

35 See Fung (1952) I, 72-73. 


\begin{abstract}
Noel: Yeu tsu Confucii discipuli effatum: in urbanitatum et rituum usu quod maxime spectatur est naturalis hos et illas servandi modus. Et ideo eorum regulae, a priscis imperatoribus sancitae, censentur praeclarae; quia quidquid dirigunt sive parvum sive magnum, naturali semper modo illud dirigunt. In hoc tamen est etiam aliquid, quod non licet; si quis nempe sciens urbanitatum et rituum pulchritudinem sitam esse in naturali agendi modo, continuo totus sui profusus omnia naturali quodam agat, neque se ullis honestatis et rituum legibus astringat; nec id sane est licitum agere.
\end{abstract}

Couvreur: Iou philosophus ait: in mutuorum officiorum observantia, concordia magno pretio habenda est. Antiquorum regum praecepta ideo optima sunt. Tum minora tum maiora, orta sunt ex hac (concordiae componendae voluntate). Est quod non (licet) agere; (nempe), scire concordiam (magno pretio habendam), et colere concordiam, (at) non iuxta officiorum leges temperare eam, (illud) quidem non licet facere.

Zottoli: Yeou tse ait: rituum praxis facilitatem habet potissimam; antiquorum regum instituta inde sunt celebria, et parva et magna emanarunt inde. At est aliquid non agendum: unice videre facilitatem statimque prosequi, quin juxta ritum illam modereris, equidem non est agendum.

Cheung: $Y u$ Tzu dixit: rerum concordia est merces rituum praestandorum. Tanta fuit imperatorum praeteritorum morum pulchritudo in rebus tum magnis tum parvis. Sed aliquando hoc minus acceptum est. Cum rerum Concordia tantum sua causa exsistit, nec ritibus coercetur, id non acceptum est.

Ruggieri, as usual, is a man of the late Renaissance, who employs words Cicero would have loved: ingenuitate amorem concordiamque dishabere, humanitas, benignitas.

In particular, he seems to translate $L i$ as ingenuitas, which in Latin means also 'nobility of character'. Couplet correctly identifies the 'rites' with social duties: in officiorum usu. Noel seems to focus more on rites as 'politeness': in urbanitatum et rituum usu. Couvrer again prefers the idea of duties: in mutuorum officiorum observantia.

Zottoli and Cheung use ritus, a word that in Latin means simply 'ceremony'. Today the word ritus (rite) in the Western tradition is commonly associated with religion. ${ }^{36}$ However, as explained above, for Confucius 礼 includes all the tradition of proper social intercourse that makes society orderly and situates a person in a correct relationship with society. Legge uses, in fact, 'propriety' and not 'rite'.

36 See Ferrero (2010). 


\section{Conclusion}

The teaching of Confucius ${ }^{37}$ has an influence in all East-Asia culture, similar to Socrates and Aristotle in the West. ${ }^{38}$ "The Confucian pattern of humanistic culture has probably influenced the lives of more people over the ages than any of the other ways of life the world has known" ${ }^{39}$ China, Korea, Vietnam, and Japan are all strongly influenced by Confucianism. Although it is debatable whether Confucius should be considered the first Chinese philosopher, certainly he is indeed the most important. In particular, Confucianism inspires and permeates all Chinese culture, life, and thought, even today, even after the Cultural Revolution of the '60's and '70's that tried unsuccessfully to wipe it off Chinese society:

Even the concept of being Chinese is not at all unconnected with the whole development of Confucian culture. Fung Yu-lan asked whether it was possible for us to understand the question of being Chinese, without getting into the whole issue of the development of the Confucian tradition. From this point of view, the Confucian tradition, in fact, helped the Chinese to acquire a certain kind of cultural identity. The notion is that being Chinese is not just ethnically or regionally defined but is also culturally defined, and this partly stems from the Confucian tradition. This is a highly controversial topic. ${ }^{40}$

The influence of Confucianism is so predominant that if anyone should be asked to characterize in one word traditional Chinese way of life and culture, that word would be 'Confucian'. ${ }^{41}$

Some scholars rightly claim that if you really want to understand an author you need to read him in the original. Yet, since most of the people cannot study six or seven languages, the works of the great authors of the past and the present come to us through translations. If an author has something important to say, a translation will help to extend his reach. The Bible is the best example. The message of the Bible has converted people who have never read the original, but only translations.

A translation is a gift to humanity. A translation breaks barriers and borders. A translation also carries with it the depth and beauty of its own language. This is why the Latin translations of Confucius can enrich his meaning.

37 Confucius was born in Shandong (China) in the year 551 BCE and died about 479 BCE.

38 See Fung (1952) I, 48-49; Filippani (1964) 39; Liu (1955) 13-14.

39 Yi (1978) 1091.

40 Tu et alii (1992) 110.

41 Yi (1978) 1091. 
Latin was used regularly in Europe from the $7^{\text {th }}$ century BC to the $18^{\text {th }}$ century. Some of the most significant works in human history were written in Latin. Because of its extension in time and space, Latin is a language that has been used, at least partially, in more countries and in more varied cultures over a longer period of time than any other language in human history. (English is used today in more countries, but has a shorter history so far).

The $21^{\text {st }}$ century is the time of a rising China. It is now an economic and political superpower that affects the entire world. It is necessary in the West to understand Chinese culture and the Confucian writings are the starting point. The Latin translations of Confucius are a bridge between past and present, and between East and West.

The world of digital communication and our future daily interaction with Artificial Intelligence needs, more than ever, a serious study of languages, words, meanings 21 and the tools of communication. Studies on those early Latin translations of Confucius are not only historical research but also a valuable contribution toward increasing the overall wisdom of mankind. 